\title{
Functional expression, characterization, and application of human S100B
}

\author{
LEI WU $^{1^{*}}$, XUESI ZHOU ${ }^{1 *}$, ZHIGANG XIAO $^{1,2}$, XIUJIE GAO $^{1}$, ZIQUAN LIU $^{1,3}$, \\ ZHIQING ZHANG ${ }^{1}$, KUN WANG ${ }^{1,3}$, YULIN ZHU ${ }^{1}$, HANLIN REN $^{1}$ and TIANHUI WANG ${ }^{1}$ \\ ${ }^{1}$ Performance Medicine Laboratory, Tianjin Institute of Health and Environmental Medicine, \\ Tianjin 300050; ${ }^{2}$ School of Materials Science and Engineering, Tianjin University of Technology, \\ Tianjin 300384; ${ }^{3}$ Institute of Disaster Medicine and Public Health, The Affiliated Hospital of \\ Logistic University of Chinese People's Armed Police Force (PAPF), Tianjin 300162, P.R. China
}

Received March 14, 2017; Accepted August 7, 2017

DOI: $10.3892 /$ or.2017.5922

\begin{abstract}
The EF-hand calcium-binding protein S100B presents a wide range of biological activities and functions. This binding protein is involved in various human diseases, including cancer, brain trauma and ischemia, neurodegenerative disease (Alzheimer's disease), and psychiatric disorders. In this study, we prepared human S100B protein and its monoclonal antibodies. Human S100B protein was expressed in Escherichia coli, successfully purified by diethylaminoethyl cellulose anion-exchange chromatography, and then identified by western blot analysis. Monoclonal antibodies (mAbs) were produced by the standard hybridoma method and validated by enzyme-linked immunosorbent assay and western blot analysis. The prepared human S100B protein and its mAbs demonstrated potential biological activities. The KD of one $\mathrm{mAb}$ is approximately $4.72 \times 10^{-8} \mathrm{~mol} / 1$, and its cross reactivity is low with human S100A4, mouse S100A4, and human S100A1. Recombinant Soluble S100B can promote the migration and invasion of HeLa cells. The expression of S100B protein in tumor tissues can be detected effectively by using the prepared monoclonal antibodies. Increasing concentration of the antihuman S100B mAbs showed a reduced expression of the S100B protein. Subsequently, the expression of p53 increased significantly $(\mathrm{P}<0.05)$ in A375 cells. A significant increase in apoptosis in A375 cells was observed with increasing S100B mAb concentration. Results showed that our prepared S100B mAbs were suitable for detecting S100B expression in human tissues, furnishing promising tools for further functional investigation and clinical applications.
\end{abstract}

Correspondence to: Professor Tianhui Wang, Performance Medicine Laboratory, Tianjin Institute of Health and Environmental Medicine, 1 Dali Road, Tianjin 300050, P.R. China

E-mail:wydny668@163.com

${ }^{*}$ Contributed equally

Key words: application, human S100B protein, monoclonal antibody, purification

\section{Introduction}

S100 proteins are associated with a multigenic family of small proteins $(10 \mathrm{kDa})$ that bind calcium via E-F hand motifs. To date, at least 25 constituents of this protein family have been identified in vertebrates. S100B is the first member of the S100 protein family to be identified and the most active S100 protein in the brain. S100B consists primarily of S100 $\beta \beta$ homodimers. This protein is highly abundant in astroglial and oligodendroglial cells, and therefore has been considered as a glial marker protein $(1,2)$. The S100B protein provides a wide range of biological activities and functions. This protein regulates cell shape, energy metabolism, contraction, cellto-cell communication, intracellular signal transduction, and cell growth. Moreover, S100B may play a crucial role in the pathogenesis of depression and its treatment. High levels of S100B have been detected in various clinical conditions, such as brain trauma and ischemia, as well as neurodegenerative, inflammatory, and psychiatric disorders (3). Cancers such as glioblastoma in cell culture have also been shown to secrete S100B (4). Moreover, S100B is a well-established prognostic marker for melanoma, and high serum concentration of S100B correlates with poor prognosis $(5,6)$.

At present, research on the function of S100B protein is comprehensive, but the regulatory mechanisms, particularly in tumorigenesis, require further studies. Therefore, the possibility of generating the whole S100B protein by recombinant techniques is significantly advantageous for such applications. However, studies on the biochemical roles and distribution of the S100B protein and its antibodies have been hampered by technical problems, such as difficulty in preparation and cross reactivity of available antibodies. In our previous study, the human S100A4 protein was successfully expressed in Escherichia coli, and an efficient method was developed to produce biologically active S100A4 (7). We attempted to utilize the previously described techniques to produce the human S100B protein. In the present study, we describe the construction and expression of a synthetic gene encoding S100B in E. coli. We also tested the bioactivity by Transwell migration and invasion assays. We injected soluble human S100B protein to mice as an antigen and produced four 
hybridoma cell lines to generate antibodies against S100B. Three monoclonal antibodies (mAbs) were generated against S100B, namely, $4 \mathrm{E}_{10} \mathrm{~F}_{11}, 3 \mathrm{D}_{2} \mathrm{E}_{5}$, and $4 \mathrm{~F}_{3} \mathrm{~A}_{5}$, and were selected for further research because of their potential characteristics and functionality in western blot analysis through an indirect enzyme-linked immunosorbent assay (ELISA).

\section{Materials and methods}

Reagents. Cloning vector pMD18-T vector was purchased from TransGen Biotech (Beijing, China). A375 cell line was obtained from the American Type Culture Collection (Manassas, VA, USA). NdeI, XhoI, and T4 DNA ligases were purchased from New England Biolabs, Ltd. (Beijing, China). Isopropyl- $\beta$-d-thiogalactopyranoside (IPTG) was purchased from Merck \& Co., Inc. (Darmstadt, Germany). QIA quick gel extraction and nucleotide removal kits were obtained from Qiagen China Co., Ltd. (Shanghai, China). Commercial recombinant human $\mathrm{S} 100 \mathrm{~B}$ protein and $\mathrm{S} 100 \mathrm{~B}$ antibody were from Abcam (Cambridge, MA, USA). Unless otherwise stated, other reagents and materials were performed as described in the literature (7). Animals were purchased from the Experimental Animal Room of the Institute of Health and Environmental Medicine (Tianjin, China). This study was approved by the Committee of the Institute of Health and Environmental Medicine.

Construction of expression vector pET32a-S100B. The gene fragment of human S100B was constructed by overlapping polymerase chain reaction (PCR) after optimization. NdeI and $X h o I$ restriction sites were designed in sense and antisense primers, respectively. Eight oligonucleotide primers with mutual overlaps were synthesized based on the codon preference in E. coli (Table I). The NdeI restriction site (underlined) was contained in the forward primer (5'-CGCCATATGTCT GAACTGGAAAAAGCC-3'), whereas the XhoI restriction site (underlined) was contained in the reverse primer (5'-CGG CTCGAGTCACTCATGTTCAAAGAAC-3'). E. coli DH5 $\alpha$ cells were transformed with the constructed cloning vector pMD18-S100B plasmid. Standard PCR was used to screen the positive plasmid. To identify the integrity of S100B, pMD18-S100B plasmid was DNA sequenced (Invitrogen Life Technologies, Shanghai, China). The expression vector pET32a-S100B plasmid was constructed and then ligated with the coding region of human S100B from the pMD18-S100B plasmid.

Expression, purification, and identification of recombinant human $S 100 B$. The expression vector $\mathrm{pET} 32 \mathrm{a}-\mathrm{S} 100 \mathrm{~B}$ plasmids were transformed into E. coli BL21 (DE3). Positive E. coli was inoculated in $5 \mathrm{ml}$ of Luria-Bertani (LB) media containing $50 \mu \mathrm{g} / \mathrm{ml}$ ampicillin. IPTG was used to induce the expression of human S100B protein. Bacterial lysate was collected to isolate the recombinant S100B. S100B was purified by ion-exchange chromatography column $\left(\right.$ HiTrap $^{\mathrm{TM}}$ DEAE FF; binding buffer: Tris- $\mathrm{HCl} 0.02 \mathrm{~mol} / 1, \mathrm{pH} 8.8$; and elution buffer: $500 \mathrm{mmol} / 1 \mathrm{NaCl}$ Tris-HCl $0.02 \mathrm{~mol} / 1, \mathrm{pH} 8.8$; GE Healthcare Life Sciences, Chalfont, UK) in accordance with the manufacturer's instructions, desalted, and freeze dried. Protein concentration was determined by bicinchoninic acid
(BCA) method (BCA Protein Assay kit; Tiangen Biotech Co. Ltd., Beijing, China) (7), and S100B protein was characterized by western blot analysis.

Biological activity of human $S 100 B$ protein in promoting HeLa cell invasion and migration. Cell motility and invasion assays were performed in a Transwell chamber to detect whether the recombinant $\mathrm{S} 100 \mathrm{~B}$ protein can stimulate cell migration and invasion (8). In accordance with the manufacturer's instructions, Transwell chambers (EMD Millipore) were coated with Matrigel ${ }^{\circledR}$, and assays were performed. HeLa cells $\left(1 \times 10^{5}\right)$ without S100B protein were utilized as the control group (C), whereas HeLa cells $\left(1 \times 10^{5}\right)$ with $50 \mu \mathrm{g} / \mathrm{ml}$ $\mathrm{S} 100 \mathrm{~B}$ protein were used as the experimental group (E). HeLa cells $(100 \mu \mathrm{l})$ of $\mathrm{C}$ or $\mathrm{E}$ were added to the top chambers of 24-well Transwell plates. After $12 \mathrm{~h}$ of incubation at $37^{\circ} \mathrm{C}$, the HeLa cells at the bottom of each chamber were fixed with $0.1 \% \mathrm{v} / \mathrm{v}$ glutaraldehyde for $30 \mathrm{~min}$, rinsed with PBS, and then stained with $0.2 \% \mathrm{v} / \mathrm{v}$ crystal violet for $20 \mathrm{~min}$, whereas the motile cells at the top of each chamber were removed with cotton swabs. The number of migrating cells or invasive cells was calculated under x200 magnification (Olympus CKX31; Olympus, Tokyo, Japan). The number of average cells per chamber was also determined. Duplicate experiment was performed with each assay and repeated at least thrice. Data were measured as the migration/invasion rates relative to the parental control cells.

Monoclonal anti-human $S 100 B$ antibody preparation, purification, and identification. The immunization procedure was performed using a previously described technique with slight modification (7,9,10). Female BALB/c mice (weight, 18-25 g; age, 8-10 weeks old) were provided by the Experimental Animal Room of the Tianjin Institute of Health and Environmental Medicine. Four mice were bred per cage at $22-25^{\circ} \mathrm{C}$, ad libitum with tap water and standard diet, under an alternating $12 \mathrm{~h}$ light/dark cycle. The purified recombinant $\mathrm{S} 100 \mathrm{~B}(50 \mu \mathrm{g})$ was mixed with an equal volume of Freund's complete adjuvant, which was multipoint-injected subcutaneously on the back of the mice. Animals were immunized thrice over the course of 45 days with purified recombinant $\mathrm{S} 100 \mathrm{~B}$ protein. On the 10 th day after the last injection, the mice were sacrificed by cervical dislocation, and the splenocytes were collected and fused with SP2/0 myeloma cells by using the PEG (PEG, polyethylene) method. Hybridoma cells were selected in the hypoxanthine, aminopterin, and thymidine media (purchased from Gibco Life Technologies, Grand Island, NY, USA). Positive hybridoma cell lines were obtained following three subcloning cycles and were confirmed by indirect ELISA. Hybridoma cells were injected intraperitoneally into liquid paraffin-primed female BALB/c mice (8-10 weeks old) at $\sim 1 \times 10^{6}$ cells/mouse to produce antiS100B mAbs. Purification of antibodies was performed using HiTrap protein G HP (1 ml) (GE Healthcare Life Sciences) in accordance with the manufacturer's instructions. The binding buffer was $20 \mathrm{mmol} / 1 \mathrm{Na}_{3} \mathrm{PO}_{4}$ at $\mathrm{pH} 7.0$, and the elution buffer was $0.1 \mathrm{~mol} / \mathrm{l} \mathrm{Gly}-\mathrm{HCl}$ at $\mathrm{pH} 2.7$. The purity of the antibody was determined by SDS-PAGE and western blot analysis. The affinity constants of antibodies were identified by $\operatorname{SPR}(11,12)$. 
Table I. Oligonucleotide primers with mutual overlaps.

\begin{tabular}{llc}
\hline $\begin{array}{l}\text { Primer } \\
\text { name }\end{array}$ & \multicolumn{1}{c}{ Primer sequence } & $\begin{array}{c}\text { Length of } \\
\text { primer (bp) }\end{array}$ \\
\hline 1 & ATGTCTGAACTGGAAAAAGCCATGGTGGCCCTGATCGACGTTTTCCACCAGT & 52 \\
2 & CTTCAGCCTGTGCCTGTCGCCTTCGCGGCCAGAATACTGGTGGAAAACGTCGATC & 55 \\
3 & ACAGGCACAGGCTGAAGAAATCCGCACCGAAGGCGCTCATCAGCAGTGAGCTT & 53 \\
4 & AACCTCCTGCTCTTTGATTTCCTCTAAGAAATGGGAAAGCTCACTGCTGATGAGC & 55 \\
5 & ATCAAAGAGCAGGAGGTTGTGGACAAAGTCATGGAAACACTGGACAATGATGGAG & 55 \\
6 & CAAAGGCCATGAATTCCTGGAAGTCACATTCGCCGTCTCCATCATTGTCCAGTGT & 55 \\
7 & AGGAATTCATGGCCTTTGTTGCCATGGTTACTACTGCCTGCCACGAGTTC & 50 \\
8 & TCACTCATGTTCAAAGAACTCGTGGCAGGCAGT & 30 \\
BF & CGCCATATGTCTGAACTGGAAAAAGCC & 27 \\
BR & CGGCTCGAGTCACTCATGTTCAAAGAAC & 28 \\
\hline
\end{tabular}

Table II. Features of S100B MAbs.

\begin{tabular}{lccc}
\hline Parameters & $4 \mathrm{E}_{10} \mathrm{~F}_{11} \mathrm{C}_{11}$ & $3 \mathrm{D}_{2} \mathrm{E}_{5} \mathrm{~F}_{7}$ & $4 \mathrm{~F}_{3} \mathrm{~A}_{5} \mathrm{D}_{5}$ \\
\hline Titer (ascitic fluid) & $1: 204800$ & $1: 204800$ & $1: 204800$ \\
Affinity constant $(1 / \mathrm{mol})$ & $6.82 \times 10^{8}$ & $7.54 \times 10^{8}$ & $2.53 \times 10^{8}$ \\
Concentration $(\mathrm{mg} / \mathrm{ml})$ & 7.5 & 6.8 & 6.6 \\
\hline
\end{tabular}

Three hybridoma cell lines, namely, $4 \mathrm{E}_{10} \mathrm{~F}_{11} \mathrm{C}_{11}, 3 \mathrm{D}_{2} \mathrm{E}_{5} \mathrm{~F}_{7}$, and $4 \mathrm{~F}_{3} \mathrm{~A}_{5} \mathrm{D}_{5}$, were obtained after mouse immunization with soluble $\mathrm{S} 100 \mathrm{~B}$ as an antigen, cell fusion, and hybridoma cell cloning and subcloning. These cell lines stably produced anti-S100B MAbs.

Antibody titer determination. Antibody titers were measured by indirect ELISA $(11,12)$. The microtiter plates were coated with $\sim 100 \mu \mathrm{l}$ of recombinant S100B $(4 \mu \mathrm{g} / \mathrm{ml})$ and then incubated at $4^{\circ} \mathrm{C}$ overnight. The plates were washed thrice with PBS containing $0.05 \%$ Tween-20 (PBST) and blocked with 3\% BSA in PBS containing Tween-20 for $1 \mathrm{~h}$ at $37^{\circ} \mathrm{C}$. The plates were placed in different serum dilutions from immunized mice, ascites, or cell culture supernatants for $2 \mathrm{~h}$ at $37^{\circ} \mathrm{C}$ and then incubated with HRP-coupled goat anti-mouse IgG for $1 \mathrm{~h}$. The substrate used was tetramethylbenzidine (TMB). The absorbance was determined at 450 and $630 \mathrm{~nm}$ wavelengths, respectively. The specification of the mAbs were examined using competitive ELISA $(11,12)$ (Table II).

SDS-PAGE and western blot analysis of recombinant S100B. The SDS-PAGE procedure was performed as previously described with slight modification (13). The concentrations of the resolving and stacking gels were 15 and $5 \%$, respectively. The purified protein was transferred to a nitrocellulose membrane with a semi-dry electrophoretic transfer device (Jim-X Biotechnology Co., Ltd., Dalian, China). The membrane was blocked with $0.5 \mathrm{ml}$ of $10 \%$ BSA in $4.5 \mathrm{ml}$ of Tris-buffered saline/Tween-20 buffer $(10 \mathrm{ml}$ of $1 \mathrm{~mol} / \mathrm{l}$ Tris $+\mathrm{HCl}$ at $\mathrm{pH} 7.5,8.8 \mathrm{~g}$ of $\mathrm{NaCl}, 1000 \mathrm{ml}$ of ultra-pure water, and $1 \mathrm{ml}$ of $20 \%$ Tween-20) and incubated with rabbit polyclonal antibody against human S100B for $2 \mathrm{~h}$ at $25^{\circ} \mathrm{C}$.
Following the HRP-coupled goat anti-rabbit IgG, a secondary antibody was added and incubated for $45 \mathrm{~min}$.

Cross reactivity. To identify the cross reactivity (CR) of the recombinant $\mathrm{S} 100 \mathrm{~B}$ and its analogs, indirect ELISA was utilized as previously described $(12,13)$. As coated antigens, recombinant S100B, recombinant rat S100A4, human S100A4, and S100A1 were all dissolved in PBS. A diluted antibody protein of S100B was incubated with these coated antigens for $2 \mathrm{~h}$ at $25^{\circ} \mathrm{C}$. Afterward, HRP-conjugated goat anti-mouse polyclonal antibody was added and then incubated for $45 \mathrm{~min}$ at $25^{\circ} \mathrm{C}$. Finally, the absorbance was determined at $450 \mathrm{~nm}$ wavelength by using a microplate reader (Multiskan MK3; Thermo Fisher Scientific, Waltham, MA, USA).

Affinity analysis. The mAb affinity against S100B was estimated by surface plasmon resonance (SPR, AutoLab ESPRIT, Utrecht, The Netherlands). In accordance with the manufacturer's instructions, S100B was immobilized on a carboxylated sensor chip (Metrohm Auto Laboratory). Extracted mAbs were added to the immobilized chip surface. Data were analyzed using Kinetic Evaluation 5.0 software (Metrohm Auto Laboratory) and Autolab ESPRIT Data Acquisition 4.3.

Effect of anti-human $S 100 B$ mAbs on cell proliferation of A375 cells. Cell proliferation assay was determined using Cell Counting Kit-8 (CCK-8; Dojinoo Techno Research Park, Mashiki-machi, Japan). A375 cells $\left(5 \times 10^{4}\right)$ of C or E were added to the 96-well plates and incubated for $24 \mathrm{~h}$ at $37^{\circ} \mathrm{C}$. Different concentrations $(100 \mu \mathrm{g} / \mathrm{ml}, 10 \mu \mathrm{g} / \mathrm{ml}, 1 \mu \mathrm{g} / \mathrm{ml}$, $100 \mathrm{ng} / \mathrm{ml}, 10 \mathrm{ng} / \mathrm{ml}$, and $1 \mathrm{ng} / \mathrm{ml})$ of S100B mAbs $(100 \mu \mathrm{L})$ were added to the plates as the experimental group (E), whereas DMEM medium $(100 \mu 1)$ was used as the control group (C). The absorbance was determined at $450 \mathrm{~nm}$ wavelength by using a microplate reader (Multiskan MK3; Thermo Fisher Scientific).

Effect of anti-human S100B mAbs on cell apoptosis of A375 cells. Cell apoptosis assay was performed using a Histone ELISA kit (from Biosoure ${ }^{\mathrm{TM}}$; Invitrogen, Carlsbad, CA, USA). 


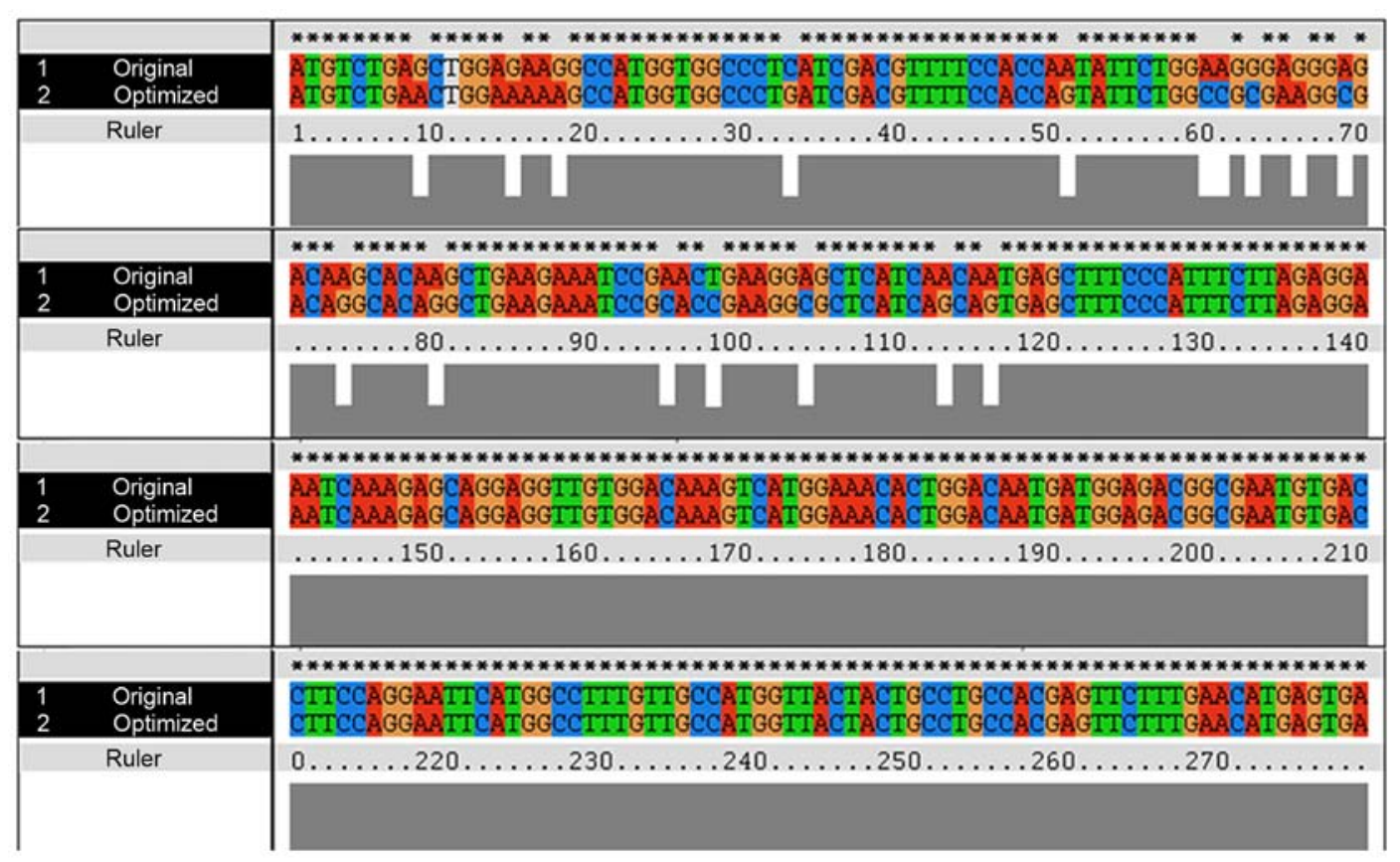

Figure 1. Alignment of S100B original and optimized sequence.

A375 cells $\left(1 \times 10^{5}\right)$ were added to the 96 -well plates. Different concentrations $(1 \mathrm{mg} / \mathrm{ml}, 100 \mu \mathrm{g} / \mathrm{ml}, 10 \mu \mathrm{g} / \mathrm{ml}, 1 \mu \mathrm{g} / \mathrm{ml}$, $100 \mathrm{ng} / \mathrm{ml}, 10 \mathrm{ng} / \mathrm{ml}$, and $1 \mathrm{ng} / \mathrm{ml})$ of S100B mAbs $(100 \mu \mathrm{l})$ were added to the plates as the experimental group (E), whereas DMEM medium $(100 \mu \mathrm{l})$ was used as the control group (C). The absorbance of the lysates of the cells was determined at $405 / 490 \mathrm{~nm}$ wavelength in accordance with the manufacturer's instructions.

Effect of anti-human $S 100 B$ mAbs on the expression of $S 100 B$ and p53 in A375 cells. To evaluate the effect of S100B mAbs on the expression of S100B and p53 in A375 cells, western blot analysis was performed. Anti-human S100B mAbs prepared in the present study was added to A375 cells in a culture flask $(25 \mathrm{~cm})$. The concentrations of S100B mAbs in the medium are $10 \mu \mathrm{g} / \mathrm{ml}$ and $100 \mathrm{ng} / \mathrm{ml}$ as the experimental group (E), whereas DMEM medium was used as the control group (C). After incubation at $37^{\circ} \mathrm{C}$ for $24 \mathrm{~h}, \mathrm{~A} 375$ cells were collected and disrupted for $30 \mathrm{~min}$. The entire set of proteins was preserved at $-70^{\circ} \mathrm{C}$. Anti-human S100B mAbs (prepared and purchased separately) were used as first antibodies in western blot analysis.

Statistical analysis. Data are shown as means \pm SD. All results were analyzed using SPSS version 17 (SPSS, Chicago, IL, USA). $\mathrm{P}<0.05$ was considered to indicate a statistically significant difference.

\section{Results}

Cloning, expression, and purification of human recombinant protein $S 100 B$. The human S100B protein natural gene sequence (Genbank accession no. NM 006272.2) was optimized using the E. coli codon. Sixteen rare codons of the S100B original gene were superseded with synonymous high-frequency codons in an optimized gene that encodes S100B (Fig. 1).
The amplified PCR products were assessed by $1.5 \%$ agarose gel. The size of the PCR products was 250-300 bp, which conforms to the expected size of 279 bp (Fig. 2A). By Ndel and Xhol digestion, the S100B gene was successfully ligated into the pMD18-T vector. Agarose gel analysis of the digestion of pMD18-S100B vector is indicated in Fig. 2B. Through DNA sequencing, the synthesized S100B gene was consistent with the optimized S100B gene without point mutation and frameshift mutation (Fig. 2D).

Recombinant $S 100 B$ protein expression and purification. S100B gene was synthesized, and the recombinant expression plasmid pET32a-S100B was constructed successfully (Fig. 2C). The results of the restriction enzyme digestion showed that the S100B gene plasmid contained the full coding sequence, and the open reading frame was correct. The recombinant plasmid pET32a-S100B was transformed into expression strain E. coli BL21 (DE3) and was induced by IPTG. The molecular weight of the S100B fusion protein was $11.5 \mathrm{kDa}$. The expressed recombinant S100B was identified by SDS-PAGE and western blotting using a rabbit anti-human S100B antibody. The recombinant S100B protein was successfully expressed in E. coli BL21 (DE3) because of the reaction with the antibody (Fig. 2F and G) and was effectively purified by ion-exchange chromatography (Fig. $2 \mathrm{H}$ ).

Recombinant $S 100 B$ protein promotes invasion and migration of HeLa cells. The function of human recombinant S100B was detected by Transwell chamber test. The results showed that the recombinant $\mathrm{S} 100 \mathrm{~B}$ protein increased the invasion of HeLa cells 2.8 times (Fig. 3A-C) and the migration 3.5 times (Fig. 3D-F), indicating that S100B protein can promote $\mathrm{HeL}$ a cell invasion and migration. The purified S100B proteins demonstrate a potential biological activity and can improve the ability of tumor cell invasion and migration. 


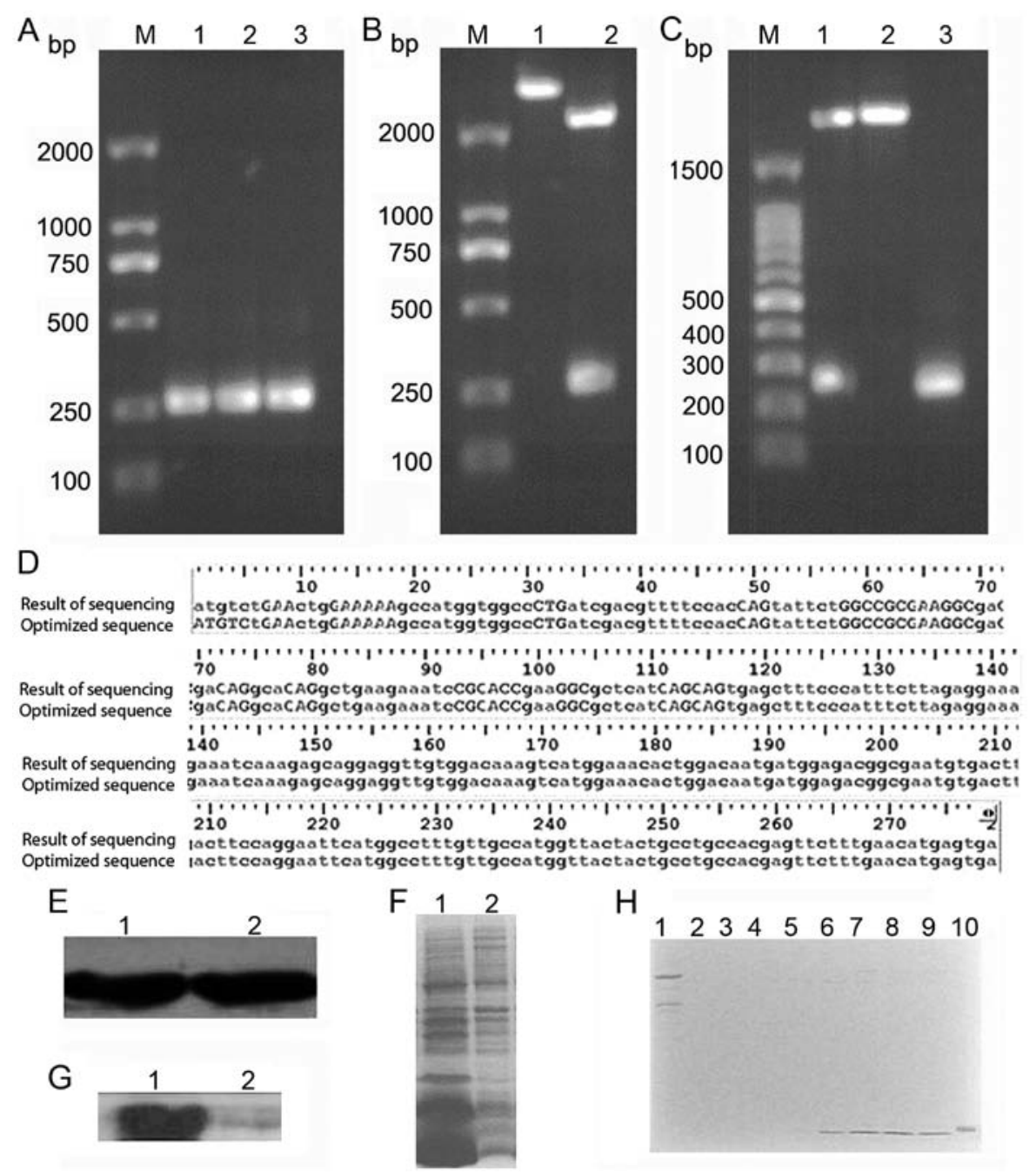

Figure 2. Recombinant expression and purification of human S100B protein. (A) Agarose gel analysis of human S100B DNA. Lanes 1-3, human S100B DNA; lane M, DNA marker. (B) Agarose gel analysis of the pMD18-S100B vector following restriction enzyme treatment by utilizing Ndel and Xhol. Lane 1, pMD18-S100B plasmid; lane 2, pMD18-S100B digested by Ndel and Xhol; lane M, DNA marker. (C) Agarose gel analysis of the pET32a-S100B expression vector following restriction enzyme treatment by utilizing $N d e l$ and Xhol. Lane 1, pET32a-S100B digested by Ndel and Xhol; lane 2, pET32a-S100B plasmid; lane 3, positive control; lane M, DNA marker. (D) DNA sequencing result. (E) Western blot analysis of purified S100B mAbs with antigen. Lanes 1, commercially purchased S100B mAbs; lanes 2, purified ascites of BALB/c mice injected hybridoma cell lines. (F) SDS-PAGE analysis of recombinant protein. Lane 1, induced products of pET32a-S100B; lane 2, induced products of pET32a; $(\mathrm{G})$ Western blot analysis of the recombinant protein. Lane 1, induced products of pET32a-S100B; lane 2, induced products of pET32a; (H) Purification of the recombinant protein. Lane 1, liquid of penetration; lanes 2-9, eluting peak of different concentrations of $\mathrm{NaCl}$; lane 3, human $\mathrm{S} 1004$ protein as a positive control.

Preparation and characterization of anti-human $100 B$ mAbs. Murine mAbs against S100B were prepared to further explore the function of human S100B. Three hybridoma cell lines, namely, $4 \mathrm{E}_{10} \mathrm{~F}_{11} \mathrm{C}_{11}, 3 \mathrm{D}_{2} \mathrm{E}_{5} \mathrm{~F}_{7}$, and $4 \mathrm{~F}_{3} \mathrm{~A}_{5} \mathrm{D}_{5}$, were subsequently formed from the immunization of mice with soluble S100B as the antigen. Highly concentrated S100B mAbs were prepared from $B A L B / c$ mouse ascites and purified by protein $G$ affinity chromatography. These cell lines stably produced anti-S100B mAbs (Table II). The specificity of the S100B mAbs was determined by western blot analysis (Fig. 2E).

CR is a key parameter used to assess the specificity of an antibody because the human S100B exhibits similar structures and functions of the following proteins: Human S100A4, Mouse S100A4, Human S100A1, and Human S100A1. The data summarized in Table III indicate that this antibody achieved little CRs to mouse S100A4, human S100A1, and S100B.

To determine the association rate constant, $3 \mathrm{D}_{2} \mathrm{E}_{5} \mathrm{~F}_{7} \mathrm{mAb}$ was properly diluted in PBS and analyzed by SPR at different
Table III. Cross-reactivity of S100B antibody.

Protein

S100B antibody $3 \mathrm{D}_{2} \mathrm{E}_{5} \mathrm{~F}_{7}$ (450 nm wavelength)

$\begin{array}{ll}\text { Human S100B } & 1.275 \\ \text { Human S100A4 } & 0.123 \\ \text { Mouse S100A4 } & 0.101 \\ \text { Human S100A1 } & 0.116 \\ \text { Negative control } & 0.092\end{array}$

concentrations (Fig. 4). The equilibrium dissociation constant (KD) for the $3 \mathrm{D}_{2} \mathrm{E}_{5} \mathrm{~F}_{7}$ clone was determined independently by Kinetic Evaluation 5.0 software. The $\mathrm{KD}$ of $3 \mathrm{D}_{2} \mathrm{E}_{5} \mathrm{~F}_{7}$ was $\sim 4.72 \times 10^{-8} \mathrm{~mol} / 1$. 


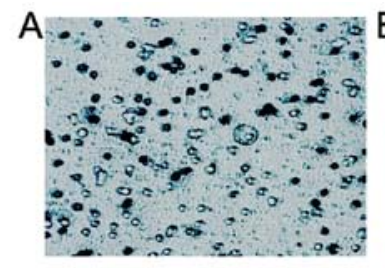

C

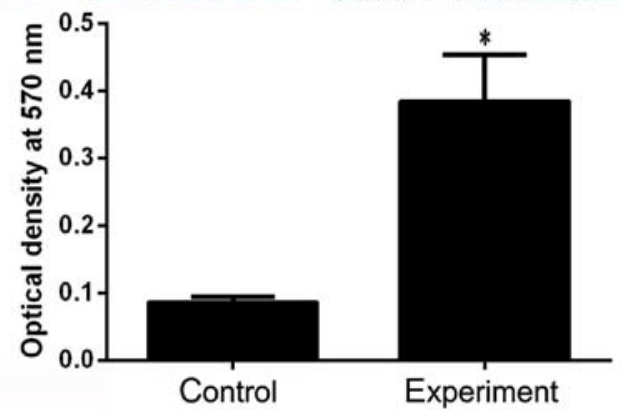

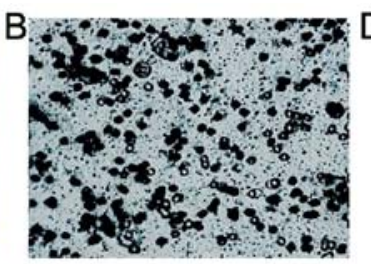

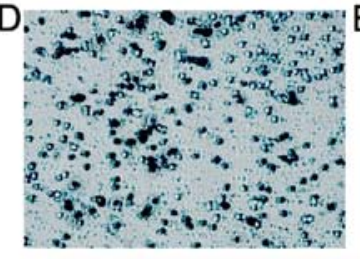

$\mathrm{F}$

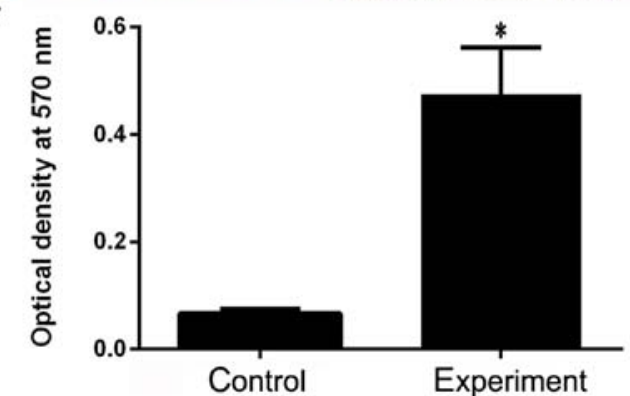

Figure 3. Increased invasion and migration of HeLa cells with recombinant S100B protein. (A) Transwell invasion of HeLa cells (2x10 ${ }^{5}$ ) added to medium without fetal bovine serum. (B) Transwell invasion of HeLa cells (1x105) added to medium with recombinant S100B protein (50 $\mu \mathrm{g} / 100 \mu \mathrm{l})$. (C) OD value of HeLa cells in the invasion experiment group compared with the control group. (D) Transwell migration of HeLa cells (1x10 ${ }^{5}$ ) added to medium without fetal bovine serum. (E) Transwell migration of HeLa cells $\left(1 \times 10^{5}\right)$ added to medium with recombinant S100B protein $(50 \mu \mathrm{g} / 100 \mu \mathrm{l})$. (F) OD value of HeLa cells in the migration experiment group compared with the control group. OD, optical density. ${ }^{*} \mathrm{P}<0.05$, compared with control.

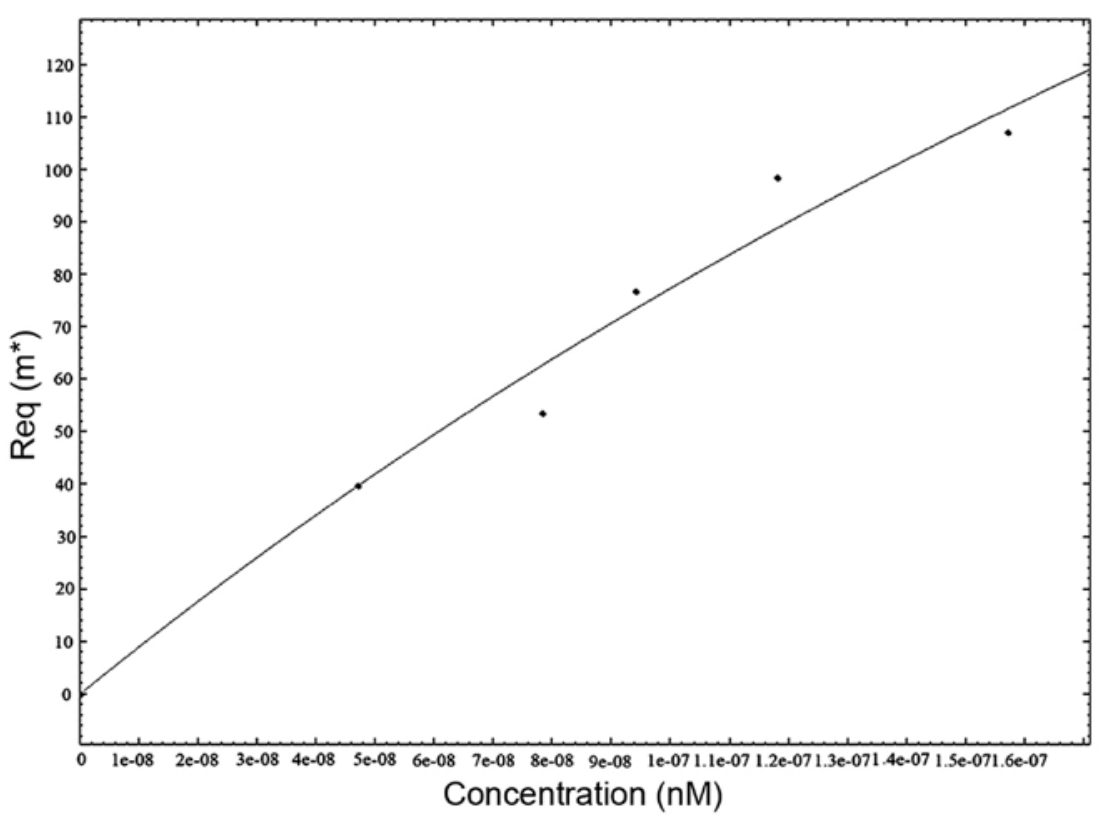

Figure 4. Plotted standard curve based on SPR data. SPR, surface plasmon resonance; Req, response of equilibrium.

Effect of anti-human $\mathrm{S1OOB}$ mAbs on cell proliferation of A375 cells. We examined the effect of S100B mAbs on cell proliferation of A375 cells. The results showed that cell proliferation of A375 cells was inhibited by anti-human S100B mAbs to some extent. Different concentrations of mAbs exert various effects on cell proliferation. The effect of mAbs on cell proliferation of A375 cells increased from low to high concentration of anti-human S100B mAbs (Fig. 5A).

Effect of anti-human $\mathrm{S100B}$ mAbs on cell apoptosis of A375 cells. To demonstrate the effect of anti-human S100B mAbs on cell apoptosis of A375 cells, cell apoptosis assay was examined in accordance with the manufacturer's instructions in the ELISA kit. The results in Fig. 5B suggest that with increasing anti-human S100B mAb concentration added to the cell culture medium, the amount of apoptosis in A375 cells was significantly increases compared with that of the control group.

Effect of anti-human $S 100 B$ mAbs on the expression of S100B and p53 in A375 cells. The results indicated that with increasing anti-human $\mathrm{S} 100 \mathrm{~B} \mathrm{mAb}$ concentration added to the cell culture medium, the expression of S100B in A375 cells decreased, whereas the expression of p53 in A375 cells increased significantly $(\mathrm{P}<0.05)$. In this study, the use of commercially purchased $\mathrm{S} 100 \mathrm{~B} \mathrm{mAb}$ was compared with that of self-prepared S100B mAb. The results presented a similar 


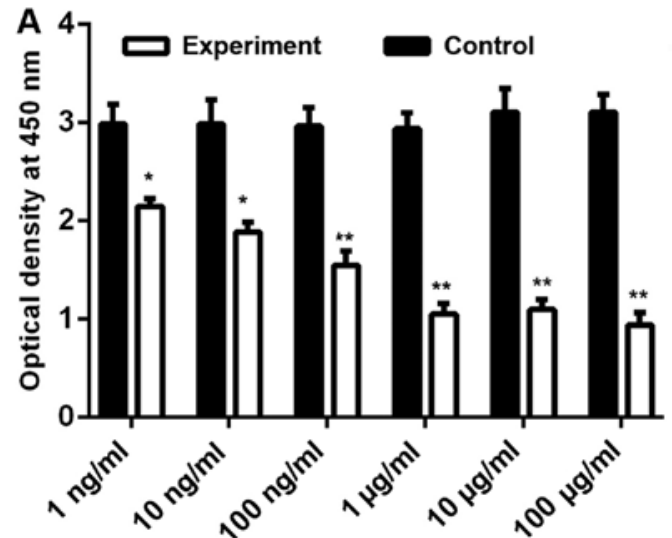

Concentration of anti-human S100B mAbs

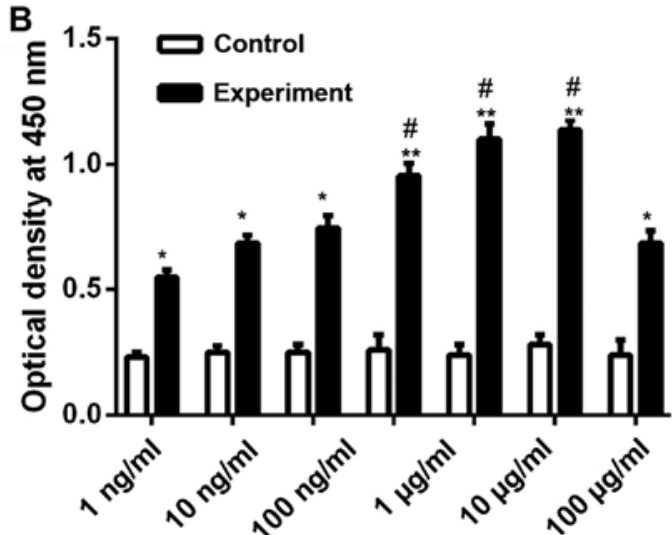

Concentration of anti-human S100B mAbs

Figure 5. Effect of anti-human S100B mAbs on cell proliferation and apoptosis of A375 cells. (A) Effect of different concentration of S100B mAbs on cell proliferation. Control, proliferation of A375 cells (5x10 $)$ added to basic medium; experiment, proliferation of A375 cells (5x10 $\left.{ }^{4}\right)$ added to different concentrations $(100 \mu \mathrm{g} / \mathrm{ml}, 10 \mu \mathrm{g} / \mathrm{ml}, 1 \mu \mathrm{g} / \mathrm{ml}, 100 \mathrm{ng} / \mathrm{ml}, 10 \mathrm{ng} / \mathrm{ml}$, and $1 \mathrm{ng} / \mathrm{ml})$ of S100B mAbs $(100 \mu 1)$. (B) Effects of different concentrations of S100B mAbs on cell apoptosis. Control, apoptosis of A375 cells $\left(1 \times 10^{5}\right)$ added to basic medium; experiment, apoptosis of A375 cells (1x10 $)$ added to different concentrations $(1 \mathrm{mg} / \mathrm{ml}, 100 \mu \mathrm{g} / \mathrm{ml}, 10 \mu \mathrm{g} / \mathrm{ml}, 1 \mu \mathrm{g} / \mathrm{ml}, 100 \mathrm{ng} / \mathrm{ml}, 10 \mathrm{ng} / \mathrm{ml}$, and $1 \mathrm{ng} / \mathrm{ml})$ of S100B mAbs $(100 \mu 1)$. OD value of HeLa cells in the invasion experiment group compared with the control group. OD, optical density. ${ }^{*} \mathrm{P}<0.05$, compared with control; ${ }^{* *} \mathrm{P}<0.01$, compared with control. ${ }^{\#} \mathrm{P}<0.05$, compared with 1 ng/ml.

A

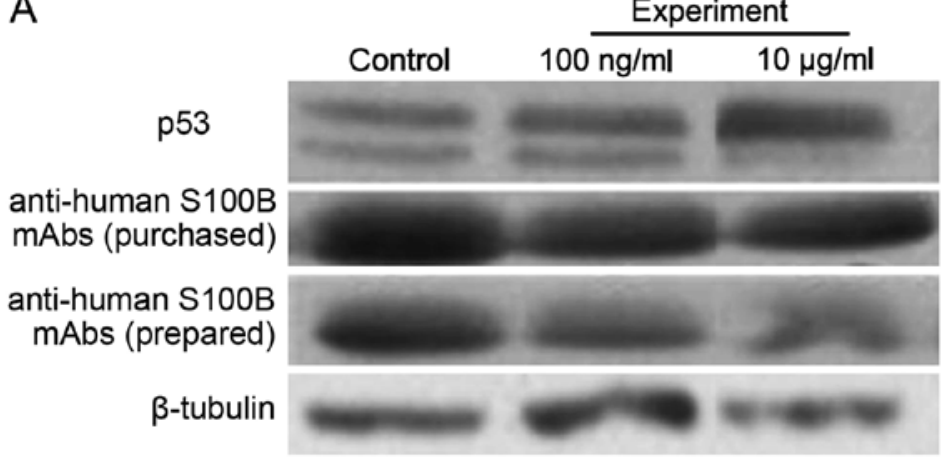

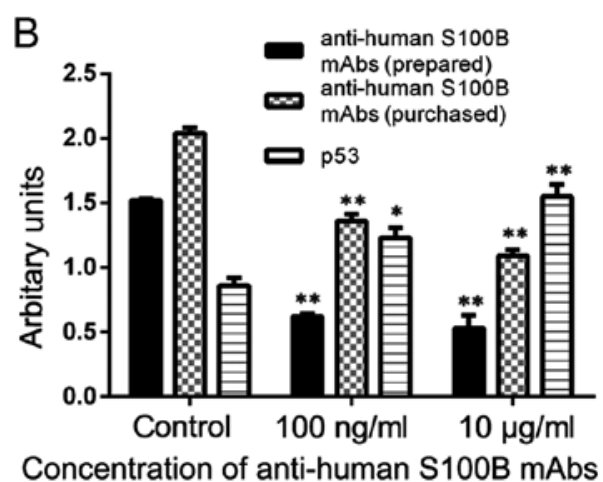

Figure 6. Effect of anti-human S100B mAbs on the expression of S100B and p53 in A375 cells. (A) Western blot analysis of effect from different concentrations of anti-human S100B mAbs on the expressions of S100B and p53 in A375 cells. Control, expression of S100B and p53 in A375 cells without S100B mAbs; experimental, expression of S100B and p53 in A375 cells added anti-human S100B mAbs (prepared) $100 \mathrm{ng} / \mathrm{ml}$ and $10 \mu \mathrm{g} / \mathrm{ml}$, respectively, to DMEM medium. Notably, anti-human S100B mAbs (purchased) and anti-human S100B mAbs (prepared) as the first antibody. $\beta$-tubulin as an internal control for this experiment. (B) Of note, the arbitrary unit value of A375 cells in the experiment group compared with the control group. ${ }^{*} \mathrm{P}<0.05$, compared with the control; ${ }^{* *} \mathrm{P}<0.01$, compared with the control.

trend. The above data illustrated that anti-human S100B mAb plays an important role in decreasing the expression of S100B and increasing the expression of P53 protein in A375 (Fig. 6).

\section{Discussion}

The S100 protein family is a group of low molecular weight, acidic, EF-hand $\mathrm{Ca}^{2+}$-binding proteins, consisting of more than 20 subfamily members. The $\mathrm{S} 100$ protein was first identified by Moor in 1965 and was named as such because it is $100 \%$ saturated in ammonium sulfate solution (14). S100 proteins are only expressed in vertebrates, showing cell-specific expression patterns and playing an important role in both intracellular and extracellular functions in the regulation of motility and differentiation, cell cycle, cytoskeletal dynamics, and $\mathrm{Ca}^{2+}$ homeostasis. In recent years, research showed that S100 proteins are involved in cardiomyopathy, neurological diseases, inflammatory, and neoplasia diseases.
$\mathrm{S} 100 \mathrm{~B}$ protein appertains to the $\mathrm{S} 100$ protein family and is mainly expressed in astrocytes and Schwann cells of the central nervous system. S100B acts as a $\mathrm{Ca}^{2+}$ sensor protein in cells. The human gene encoding S100B maps to chromosome 21q22.3 (15) with consequent overexpression of the protein in Down syndrome (16). Recently, S100B has been identified as a novel dyslexia candidate gene (17). S100B is closely related to the pathophysiological mechanism in traumatic injury (TBI) and neonatal hypoxic ischemic encephalopathy, supposing that neonatal hypoxic ischemic encephalopathy, TBI, and intracellular S100B from the injury or apoptosis of nerve cells can be released into the blood, urine, or cerebrospinal fluid. Therefore, serum, urine, or cerebrospinal fluid levels of S100B are of prognostic and predictive values in patients with related diseases.

In this study, we have successfully constructed the recombinant plasmid $\mathrm{pET} 32 \mathrm{a}-\mathrm{S} 100 \mathrm{~B}$, which was expressed in E. coli, and purified soluble recombinant S100B protein with 
biological activity. We ultimately obtained human monoclonal antibodies against S100B through immunization of mice with the purified S100B protein. S100B proteins in the human melanoma cell line A375 were detected with the monoclonal antibodies against S100B proteins. The results were all positive, and the results detected with the antibodies were the same as those with the commercial monoclonal antibody. When the monoclonal antibodies were added to A375, cell proliferation decreased and the apoptotic ratio increased, which may increase the expression of wild-type P53 protein. Thus, antibodies can play the role of targeted therapy for diseases.

In this study, the DNA sequence of human S100B was optimized and synthesized in accordance with the codon usage bias of $E$. coli, which may be improved for the soluble expression and biological activity. The following results demonstrated that the recombinant $\mathrm{S} 100 \mathrm{~B}$ protein was functionally expressed in E. coli BL21 (DE3) at a high level and showed high biological activity in the immunization procedure, antibody preparation, western blot analysis, and A375 cell model.

This study provides a favorable means for conducting qualitative and quantitative detection of S100B and is beneficial for diagnosis and treatment of related diseases. Concurrently, this study provides theoretical and technical basis for further research on standardized commercial kit diagnosis of malignant tumors and for studies on other human antibodies.

\section{Acknowledgements}

The authors gratefully acknowledge the financial support of the National Natural Science Foundation of China (grant nos. 81373108 and 30971421).

\section{References}

1. Donato R: S100: A multigenic family of calcium-modulated proteins of the EF-hand type with intracellular and extracellular functional roles. Int J Biochem Cell Biol 33: 637-668, 2001.

2. Shiras A, Bhosale A, Shepal V, Shukla R, Baburao VS, Prabhakara K and Shastry P: A unique model system for tumor progression in GBM comprising two developed human neuroepithelial cell lines with differential transforming potential and coexpressing neuronal and glial markers. Neoplasia 6: 520-532, 2003.

3. Nash DL, Bellolio MF and Stead LG: S100 as a marker of acute brain ischemia: A systematic review. Neurocrit Care 8: 301-307, 2008.
4. Dagdan E, Morris DW, Campbell M, Hill M, Rothermundt M, Kästner F, Hohoff C, von Eiff C, Krakowitzky P, Gill M, et al: Functional assessment of a promoter polymorphism in S100B, a putative risk variant for bipolar disorder. Am J Med Genet B Neuropsychiatr Genet 156B: 691-699, 2011.

5. Egberts F, Pollex A, Egberts JH, Kaehler KC, Weichenthal M and Hauschild A: Long-term survival analysis in metastatic melanoma: Serum S100B is an independent prognostic marker and superior to LDH. Onkologie 31: 380-384, 2008.

6. Weide B, Richter S, Büttner P, Leiter U, Forschner A, Bauer J, Held L, Eigentler TK, Meier F and Garbe C: Serum S100B, lactate dehydrogenase and brain metastasis are prognostic factors in patients with distant melanoma metastasis and systemic therapy. PLoS One 8: e81624, 2013.

7. Bradford MM: A rapid and sensitive method for the quantitation of microgram quantities of protein utilizing the principle of protein-dye binding. Anal Biochem 72: 248-254, 1976.

8. Wang XG, Meng Q, Qi FM and Yang QF: Blocking TGF- $\beta$ inhibits breast cancer cell invasiveness via ERK/S100A4 signal. Eur Rev Med Pharmacol Sci 18: 3844-3853, 2014.

9. Davydov DM, Lobanov AV, Morozov SG, Gribova IE and Murashev AN: Neurodevelopment and phenotype-modulating functions of S100B protein: A pilot study. Physiol Behav 140: 188-196, 2015.

10. Yang XX, Li F, Hu WG, Xia HC and Zhang ZC: Preparation and preliminary application of monoclonal antibodies against Trichokirin-S1, a small ribosome-inactivating peptide from the seeds of Trichosanthes kirilowii. Acta Biochim Biophys Sin (Shanghai) 37: 447-452, 2005.

11. Vasconcellos FA, Aleixo PB, Stone SC, Conceição FR, Dellagostin OA and Aleixo JA: Generation and characterization of new HER2 monoclonal antibodies. Acta Histochem 115: 240-244, 2013

12. Yuasa N, Koyama T and Fujita-Yamaguchi Y: Purification and refolding of anti-T-antigen single chain antibodies (scFvs) expressed in Escherichia coli as inclusion bodies. Biosci Trends 8: 24-31, 2014.

13. Wang D, Zhang J, Liu Z, Chen Y, Xu C, Zhang Z, Liu X, Wu L, Zhou X, Meng X, et al: Functional expression, characterization and application of the human S100A4 protein. Mol Med Rep 11: 175-181, 2015.

14. Bresnick AR, Weber DJ and Zimmer DB: S100 proteins in cancer. Nat Rev Cancer 15: 96-109, 2015.

15. Allore R, O'Hanlon D, Price R, Neilson K, Willard HF, Cox DR, Marks A and Dunn RJ: Gene encoding the beta subunit of S100 protein is on chromosome 21: Implications for Down syndrome. Science 239: 1311-1313, 1988.

16. Lu J, Esposito G, Scuderi C, Steardo L, Delli-Bovi LC, Hecht JL, Dickinson BC, Chang CJ, Mori T and Sheen V: S100B and APP promote a gliocentric shift and impaired neurogenesis in Down syndrome neural progenitors. PLoS One 6: e22126, 2011.

17. Poelmans G, Engelen JJ, Van Lent-Albrechts J, Smeets HJ, Schoenmakers E, Franke B, Buitelaar JK, Wuisman-Frerker M, Erens W, Steyaert J, et al: Identification of novel dyslexia candidate genes through the analysis of a chromosomal deletion. Am J Med Genet B Neuropsychiatr Genet 150B: 140-147, 2009. 